\title{
Effect of Probiotic Supplementation Shortly Before and After Weaning on Growth of Turkish Saanen Kids
}

\begin{abstract}
Sixteen kids were assigned at an average of 6 weeks of age to two treatments: control with no supplementation and $5 \mathrm{~g} / \mathrm{kid}$ of probiotic supplementation daily. The probiotic was resuspended in distilled water and given orally every day in the morning throughout a $42 \mathrm{~d}$ study. Grower concentrate, vetch hay and water were offered ad libitum throughout the study. Kids were abruptly weaned 14 days after the initiation of the study and received only grower concentrate, vetch hay and water ad libitum from d 15 to 42 . The supplementation of probiotic did not result in any significant differences in weight gain, nutrient intake, feed efficiency and diarrhea score in kids. However a positive trend toward improved weight gain, feed intake and feed efficiency in kids supplemented with probiotic suggested that probiotic might improve growth and performance of kids and are worth further investigation.
\end{abstract}

Key Words: Turkish Saanen goats, diarrhea, weight gain, probiotic

\section{Zusammenfassung}

Titel der Arbeit: Einfluss einer Probiotika-Verabreichung kurz vor und nach dem Absetzen auf das Wachstum von türkischen Saanen Ziegenlämmern

Sechzehn türkische Saanen Ziegenlämmer wurden in einem durchschnittlichen Alter von 6 Wochen in zwei Behandlungsgruppen aufgeteilt; eine Kontrollgruppe und eine Probiotikagruppe (5 g/Tag pro Lamm). Während des 42 Tage dauernden Versuches wurde das Probiotikum morgens, gelöst in destilliertem Wasser, oral verabreicht. Während der ganzen Versuchsperiode standen das Aufzuchtfutter, das Luzerneheu und das Wasser den Tieren ad libitum zur Verfügung. Das Absetzen erfolgte nach 14 Tagen. Die Verabreichung von Probiotika hatte keinen Einfluss auf die tägliche Gewichtszunahme, die Futteraufnahme, die Futtereffizienz und die Durchfallquote der Lämmer. Ein positiver Trend war jedoch durch die Probiotika-Verabreichung bei den Merkmalen tägliche Gewichtszunahme, Futteraufnahme und Futtereffizienz ersichtlich. Bezüglich der Probiotika-Anwendung bei Ziegenlämmern sind weitere Untersuchungen unentbehrlich.

Schlüsselwörter: Türkische Saanenziegenlämmer, Durchfall, Gewichtszunahme, Probiotika

1. Introduction

A strong relationship is present between the microbial activity in the gut and the host. SNOEYENBOS (1989) described the microbial activity in the gut as the first barrier in the defense mechanism of the host against disease-causing factors. However environmental factors appearing in different periods of life lead to imbalances in the microbial population of the gut, which can have negative consequences for the host animal. Disease-causing factors and environmental conditions into which newborn animals are exposed, and other stress-causing environmental factors such as weaning, transport and inadequate housing can result in imbalances in the composition of microbial population (JONSSON, 1985). A great deal of research has been directed to investigating the effect of provision of microorganisms which are natural members of the gut microbial flora as a supplement on health and performance traits (BEDÖ, 
1996). Probiotics are live microbial supplements which have a beneficial effect on the intestinal balance of the host animal (FULLER, 1989; HERICH et al., 1998).

Probiotics are widely used in dairy and beef cattle production. KREHBIEL et al. (2003) reported that probiotics can decrease diarrhea as well as morbidity cases occurring after weaning or transport in neonatal calves, and can improve milk yield in lactating cows. In contrast, probiotics have not found any particular interest at the scientific level or under practical husbandry conditions in small ruminants, especially in goats. As far as the literature is concerned, there is no report on the efficacy of probiotic use in growing kids.

Pre- and post-weaning kid losses are one of the main factors which have a negative influence on productivity in goat husbandry. Various factors such as birth weight, birth type, birth season, husbandry conditions and diseases can significantly affect mortality (GORSKI et al., 2004; KUMAR et al., 2003; PETERS and LAES-FETTBACK, 1995; LAES-FETTBACK and PETERS, 1995). The mortality of the goat herd from 1997 till 2003 at the research centre where this study was carried out varied between 11 and $32 \%$ ( $n=512$ ) (unpublished report). The mortality rate of the goat herd is also representative for the goat herds of the area where the Research and Training Centre is located.

Production losses in goat husbandry also involve decreases in performance traits such as weight gain in pre- and post weaning periods which is caused by lower nutrient intake and/or feed efficiency (TOUKOUROU and PETERS, 1999). Extensive production systems have serious disadvantages in terms of control of environmental factors which result in mortality and kid losses. Evaluation of probiotics for their potential benefit on health and performance of animals under these systems can therefore be important and enhance animal production. This study was undertaken to investigate the effect of probiotic supplemented to kids shortly before and after weaning on nutrient intake, performance, diarrhea score and several physiological parameters.

2. Materials and Methods

This study was carried out at Goat Farm of Yahya Çavus Research and Training Centre, Çanakkale Onsekiz Mart University. Sixteen Turkish Saanen Goat kids with an average of 6 weeks of age ( 8 male and 8 female) were used. The animals were divided into two treatment groups: Control (CONT; $n=8)$ and Probiotic (PROB; $n=8$ ). Probiotic supplementation started when kids were at an average of 6 weeks of age and lasted for 6 weeks, consisting of a 2 week pre-weaning period and of a 4 week postweaning period.

During suckling period, kids were only allowed to stay with their dams for $45 \mathrm{~min}$ in the morning and for $45 \mathrm{~min}$ in the evening. Grower concentrate $(209.02 \mathrm{CP} / \mathrm{kg} \mathrm{DM}$; 11.7 MJ ME/kg DM) and vetch hay were offered ad libitum. At the end of the 2 week suckling period, all kids were abruptly weaned. Ad libitum feeding of grower concentrate and vetch hay was continued after weaning till the end of the study. Chemical compositions of feedstuffs fed to kids throughout the study were given in Table 1. During the suckling period, the dams were fed with daily amount of 0.5 $\mathrm{kg} /$ head barley and $1.0 \mathrm{~kg} /$ head milk concentrate (194.56 g CP/kg DM; $11.5 \mathrm{MJ}$ $\mathrm{ME} / \mathrm{kg} \mathrm{DM}$ ) in addition to oats hay ad libitum (Table 1). All kids were vaccinated against clostridial infections on d 6 of the study. 
Table 1

Chemical compositions of feedstuffs fed to dams or kids (Nährstoffzusammensetzung des Futters für die Mütter und die Lämmer)

\begin{tabular}{lccccc}
\hline \multicolumn{1}{c}{ Feedstuff } & & \multicolumn{4}{c}{ Chemical Composition $^{(1)}$} \\
& DM, g/kg & CP, g/kg DM & CC, g/kg DM & CF, g/kg DM & Ash, g/kg DM \\
\hline Vetch Hay & 910 & 77.69 & 338.79 & - & 77.80 \\
Oats Hay & 910 & 101.53 & 284.28 & - & 101.64 \\
Barley & 900 & 140.55 & 66.22 & 16.88 & 30.22 \\
Milk Concentrate & 902 & 194.56 & 151.99 & 23.05 & 80.37 \\
Grower Concentrate & 898 & 209.02 & 142.87 & 29.95 & 81.51 \\
\hline
\end{tabular}

${ }^{(1)}$ DM: dry matter; CP: crude protein; CC: crude cellulose; CF: crude fat

A commercial probiotic (BiyoteksinTM L, Novartis) that was composed of microbial

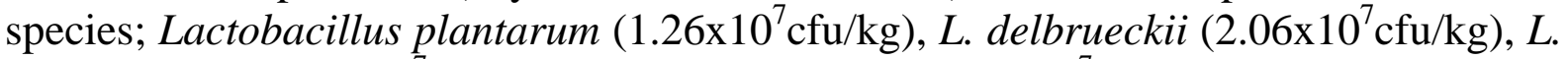
acidophilus $\left(2.06 \times 10^{7} \mathrm{cfu} / \mathrm{kg}\right), \quad$ L. rhamnosus $\left(2.06 \times 10^{7} \mathrm{cfu} / \mathrm{kg}\right)$, Bifidobacterium bifidum $\left(2.00 \times 10^{7} \mathrm{cfu} / \mathrm{kg}\right)$, Streptococcus salivarius $\left(4.10 \times 10^{7} \mathrm{cfu} / \mathrm{kg}\right), \quad$ S. facium $\left(5.90 \times 10^{7} \mathrm{cfu} / \mathrm{kg}\right)$, Aspergillus oryza $\left(5.32 \times 10^{7} \mathrm{cfu} / \mathrm{kg}\right)$ and Candida pintolopesii $\left(5.32 \times 10^{7} \mathrm{cfu} / \mathrm{kg}\right)$, and of lactose as the carrier molecule was used. Population density of each of the microbial species was based on the report of the producer company. Five grams of the probiotic was suspended in $20 \mathrm{ml}$ of distilled water and given orally every morning to each kid in the PROB treatment group throughout the $42 \mathrm{~d}$ study. Same volume of distilled water was also given to each kid in the CONT group.

Milk intake of each kid was determined by the weight difference before and after suckling daily. Milk remaining was milked right after suckling and daily milk yield of each dam was determined. All kids were weighed just before placement to treatment groups and at weekly intervals during the 6 week trial. Grower concentrate intake and water intakes were recorded daily on group basis.

Feces were observed daily and consistency was scored by using a diarrhea score scaling system ranging from 1 to 4 (1=watery; 2=runny; $3=$ soft; $4=$ =normal). Several physiological parameters of kids such as breath number and rectal temperature were recorded on seven observation days. The temperature and relative humidity of the barn were recorded daily.

Live weight and body condition score of dams were taken at d 0, 7 and 14 of the study in order to describe the effect of nutritional conditions on kids during the suckling period. Milk samples taken on the same days were analyzed to determine the nutrient intakes of kids.

The analysis of milk samples was carried out via an auto-analyzer (MILKANA ${ }^{\circledR}$ Milk Analyzer). In the calculation of energy content of milk samples, the following equation, $\mathrm{S}_{\mathrm{E}}(\mathrm{MJ} / \mathrm{kg})=(0.18 \times$ fat $\%+0.21 \times \mathrm{DM} \%-0.24)$, was used $(\mathrm{GFE}, 2003)$. The chemical compositions of feeds were determined by analytical methods described by AOAC (1990).

The model (1) that was based on repeated measures was used in the statistical evaluation of performance and yield parameters of dams as well as weight changes of kids (WINER et al., 1991). As the dams of kids in both groups were subjected to same feeding conditions, they were grouped before the analysis as the dams of kids of the CONT or PROB group. The analyses were carried out by SAS (1999).

$$
\mathrm{Y}_{\mathrm{ijk}}=\mu+\alpha_{\mathrm{i}}+\pi_{\mathrm{k}(\mathrm{i})}+\beta_{\mathrm{j}}+\alpha \beta_{\mathrm{ij}}+\beta \pi_{\mathrm{jk}(\mathrm{i})}+\varepsilon_{\mathrm{m}(\mathrm{ijk})}
$$

In the model,

$\mathrm{Y}_{\mathrm{ijk}}$; measured value of kid $\mathrm{k}$ in group i on observation day $\mathrm{j}$; 
$\mu \quad$; overall mean;

$\alpha_{i} \quad$; group effect $\mathrm{i}$; $(\mathrm{i}=1,2 ; \mathrm{i}=1$ (control), $\mathrm{i}=2$ (probiotic)),

$\pi_{\mathrm{k}(\mathrm{i})} \quad$; random effect of kid $\mathrm{k}$ in group $\mathrm{i}$;

$\beta_{\mathrm{j}} \quad$; observation day effect $\mathrm{j},(\mathrm{j}=1,2, \ldots, \mathrm{p})$;

$\alpha \beta_{\mathrm{ij}} \quad$; effect of interaction between group i and observation day $\mathrm{j}$;

$\beta \pi_{\mathrm{jk}(\mathrm{i})}$; effect of interaction between observation day and kids in group $\mathrm{i}$; and

$\varepsilon_{\mathrm{m}(\mathrm{ijk})}$; random error term.

The diarrhea score was discrete and was correlated due to repeated measurements. Since the normality and independence assumption was violated, the effects of live weight, observation day and probiotic on diarrhea were analysed using the Generalized Estimating Equations (GEE) method in GENMOD procedure of SAS (ver. 8.0). The statistical model (2) used was;

In the model;

$$
Y_{i k l}=\mu+A_{i}+B_{k}+C_{i l}+d+A_{i k}+e_{i k l}
$$

$\mathrm{Y}_{\mathrm{ikl}}$; diarrhea score $\mathrm{m}$ of kid $\mathrm{l}$ in group $\mathrm{i}$ on observation day $\mathrm{k} ;(\mathrm{m}=1,2,3,4)$,

$\mu \quad$; overall mean;

$\mathrm{A}_{\mathrm{i}} \quad$; group effect $\mathrm{i}$; $(\mathrm{i}=1,2 ; \mathrm{i}=1$ (control), $\mathrm{i}=2$ (probiotic)),

$\mathrm{B}_{\mathrm{k}} \quad$; observation day effect $\mathrm{k},(\mathrm{k}=1,2, \ldots, 42)$;

$\mathrm{C}_{\mathrm{il}} \quad$; random effect of kid $\mathrm{l}$ in group $\mathrm{i}$;

d ; linear effect of live weight,

$\mathrm{AB}_{\mathrm{ik}}$; effect of interaction between group i and observation day $\mathrm{k}$; and $\mathrm{e}_{\mathrm{ikl}}$; random error term.

GENMOD procedure of SAS (ver. 8.0) for fitting Generalized Linear Models (McCULLAGH and NELDER, 1989) was used for analysis. The data were correlated in time and modeled via the REPEATED statement of SAS to use the GEE estimation method of LIANG and ZEGER (1986). The GEE method is an extension of the independence estimating equation to correlated data and is given by

$\mathrm{S}(\beta)=\sum_{\mathrm{i}=1}^{\mathrm{K}} \frac{\partial \mu_{\mathrm{i}}^{\prime}}{\partial \beta} \mathrm{V}_{\mathrm{i}}^{-1}\left(\mathrm{Y}_{\mathrm{i}}-\mu_{\mathrm{i}}(\beta)\right)=0$

Since $g\left(\mu_{i j}\right)=X_{i j} \beta$

Where $g$ is the link function, the $\mathrm{p} \times \mathrm{n}_{\mathrm{i}}$ matrix of partial derivatives of the mean with respect to the regression parameters for the ith subject is given by

$\frac{\partial \mu_{i}^{\prime}}{\partial \beta}=\left(\begin{array}{ccc}\frac{X_{i 11}}{g^{\prime}\left(\mu_{i 1}\right)} & \cdots & \frac{X_{i n_{i} 1}}{g^{\prime}\left(\mu_{i n_{i}}\right)} \\ \vdots & \ddots & \vdots \\ \frac{X_{i 1 p}}{g^{\prime}\left(\mu_{i 1}\right)} & \cdots & \frac{X_{i n_{i} p}}{g^{\prime}\left(\mu_{i n_{i}}\right)}\end{array}\right)$

(SAS V8.0, 1999).

ESTIMATE statement of SAS was used to test the differences between the groups. Cumulative logit function was used for GEE analysis since the distribution was multinominal. LIPSITZ et al. (1994) reported how to extend GEEs to multinominal data (SAS, 1999). 
No statistical analysis of feed or water intakes data was performed since these data were collected on group basis. Only descriptive statistics of the data were discussed.

\section{Results}

The analyses of the data involving live weight, body condition score, milk yield and milk components of dams, which were collected on three separate observation days during the suckling period indicated no significant differences between the dams of both groups $(\mathrm{P}>0.05)$. However changes in all traits except for milk yield, body condition score, milk protein and lactose on different observation days were found significant $(\mathrm{P}<0.01)$. Day $\times$ group interaction had no effect on these traits $(\mathrm{P}>0.05)$. The data of the dams obtained on different observation days were presented in Table 2.

Table 2

Performance and milk data of dams on different observation days (Leistungsdaten der Mütter an verschiedenen Beobachtungstagen)

\begin{tabular}{|c|c|c|c|c|c|c|c|}
\hline \multirow{3}{*}{ Traits $^{(1)}$} & \multicolumn{6}{|c|}{ Observation Day } & \multirow{3}{*}{$P^{(2)}$} \\
\hline & \multicolumn{2}{|c|}{0} & \multicolumn{2}{|c|}{7} & \multicolumn{2}{|c|}{14} & \\
\hline & Mean & SE & Mean & SE & Mean & SE & \\
\hline $\mathrm{LW}, \mathrm{kg}$ & 42.919b & 1.368 & $43.403 \mathbf{b}$ & 1.258 & $47.719 a$ & 1.553 & $* * *$ \\
\hline BCS & 2.542 & 0.046 & 2.517 & 0.095 & 2.546 & 0.112 & 0.882 \\
\hline MY, kg/d & 2.137 & 0.076 & 1.988 & 0.118 & 1.951 & 0.085 & 0.377 \\
\hline DM, \% & $13.415 \mathbf{b}$ & 0.167 & $12.888 c$ & 0.173 & $14.174 a$ & 0.198 & $* * *$ \\
\hline SNF, \% & $9.573 \mathbf{b}$ & 0.118 & $9.210 \mathrm{c}$ & 0.123 & $10.296 \mathbf{a}$ & 0.099 & $* * *$ \\
\hline Fat, \% & $4.285 a$ & 0.345 & $2.307 \mathbf{b}$ & 0.155 & $3.117 c$ & 0.152 & $* * *$ \\
\hline Protein, \% & 5.139 & 0.063 & 4.954 & 0.065 & 4.742 & 0.165 & 0.069 \\
\hline Lactose, \% & 3.842 & 0.049 & 3.678 & 0.050 & 3.878 & 0.148 & 0.205 \\
\hline Energy, MJ/kg & $3.348 \mathbf{a}$ & 0.092 & $2.882 \mathbf{b}$ & 0.063 & $3.297 \mathbf{a}$ & 0.065 & $* * *$ \\
\hline
\end{tabular}

${ }^{(1)} \mathrm{LW}$ : live weight; BCS: body condition score; MY; milk yield; DM: dry matter; SNF: solids-not-fats.

${ }^{(2)}$ Means with different superscripts are statistically different, $* * * \mathrm{P}<0.001$.

Probiotic use had no significant effect on live weight or daily weight gain of kids as compared to the control treatment throughout the study (Figures 1a\&b; $\mathrm{P}>0.05$ ). However PROB group appeared to have weight gain values higher than the CONT group in all weeks except for the first week after weaning (Figure 1b). A similar pattern was also present for average live weight values (Figure 1a).
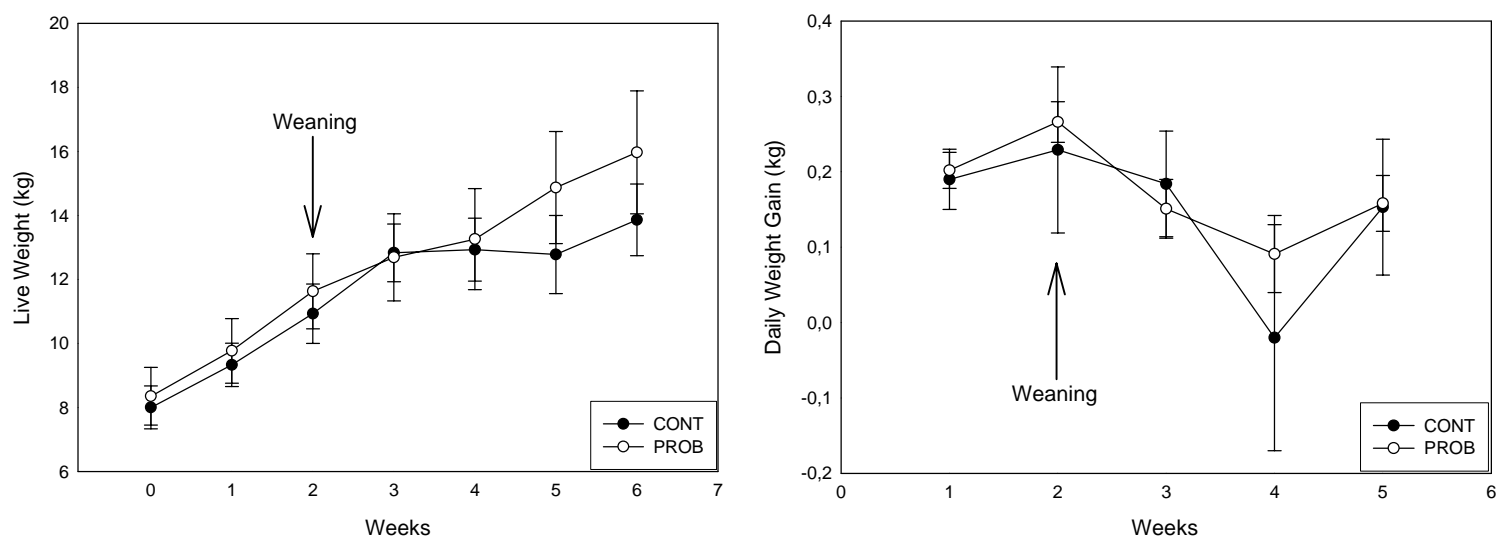

Fig. 1: Average live weights (a) and daily weight changes (b) with SEDs of kids (Mittelwerte und SEDs für das Lebendgewicht (a) und tägliche die Gewichtszunahme der Lämmer (b))

Weight gain of the CONT and PROB groups in the suckling period (0-2 w) was $0.209 \pm 0.02$ and $0.234 \pm 0.02 \mathrm{~kg} / \mathrm{d}$, respectively. However weight gain decreased in both groups after weaning. Average weight gain of kids throughout the study (6 weeks) was 
$0.131 \pm 0.01 \mathrm{~kg} / \mathrm{d}$ for the CONT group and $0.168 \pm 0.02 \mathrm{~kg} / \mathrm{d}$ for the PROB group. The effect of observation day was found significant $(\mathrm{P}<0.001)$, however the effect of observation day $\times$ treatment interaction was not significant $(\mathrm{P}>0.05)$.

Daily milk intakes of kids were not affected by treatment or day $\times$ treatment interaction $(\mathrm{P}>0.05)$. Daily milk intakes varied significantly throughout 14 days of the suckling period (Figure 2a; $\mathrm{P}<0.01$ ). Daily average milk intakes of kids for the CONT and PROB groups were $1.184 \pm 0.142$ and $1.193 \pm 0.142 \mathrm{l} / \mathrm{d}$, respectively.

Milk efficiencies for the CONT and PROB groups were $5.95 \pm 0.530$ and $5.44 \pm 0.730$, respectively. No statistical difference was found in milk efficiency between the groups $(\mathrm{P}>0.05)$. In both groups, milk efficiency improved in the second week of the suckling period as compared to the first week $(\mathrm{P}<0.01)$. The effect of week $\times$ treatment interaction was not significant $(\mathrm{P}>0.05)$.
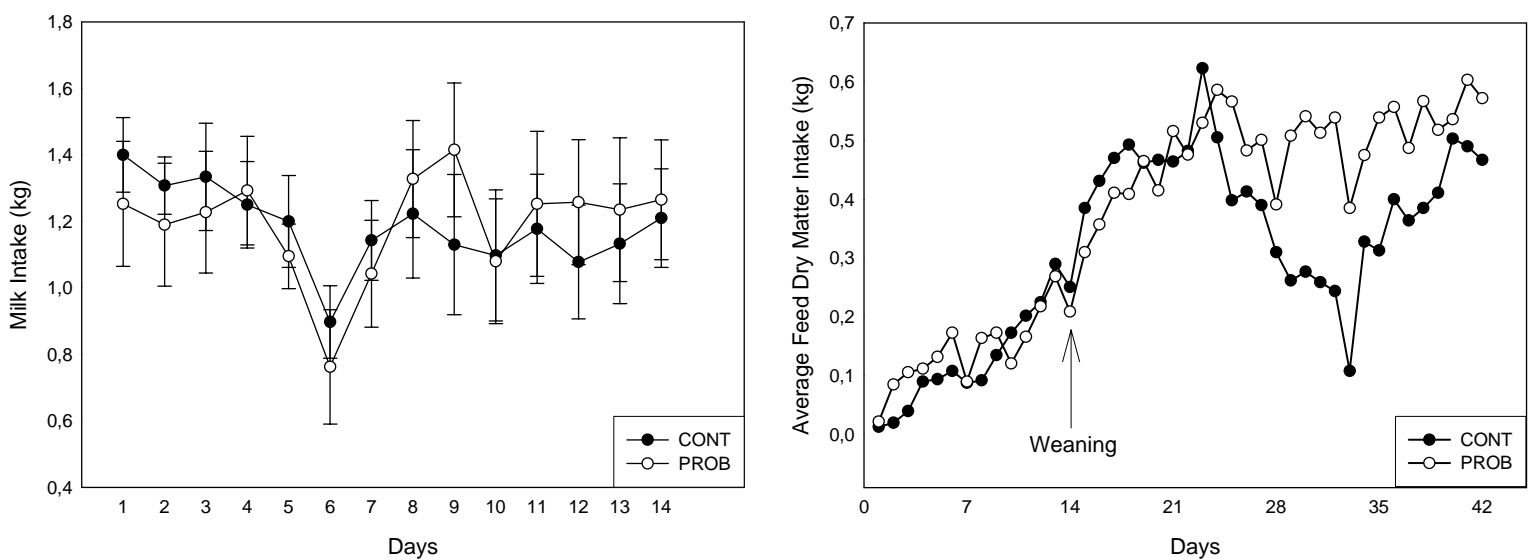

Fig. 2: Average milk intakes with SEDs (a) and average feed dry matter intakes (b) of kids (Mittelwerte und SEDs für die Milchaufnahme (a) und die durchschnittliche Trockenmassenaufnahme der Lämmer (b))

Probiotic supplementation had no effect on intake of milk components by kids ( $\mathrm{P}>0.05)$, but the differences determined on the observation days were significant (Table 3). No day $\times$ treatment interaction was found in the observed differences of milk component parameters $(\mathrm{P}>0.05)$.

Table 3

Average milk-based nutrient intakes of kids on different observation days (Mittelwerte und Standardfehler (SE) an unterschiedlichen Beobachtungstagen für die milchbezogene Nährstoffaufnahme der Lämmer)

\begin{tabular}{|c|c|c|c|c|c|c|c|}
\hline \multirow{3}{*}{ Traits $^{(1)}$} & \multicolumn{6}{|c|}{ Observation Day } & \multirow{3}{*}{$P^{(2)}$} \\
\hline & \multicolumn{2}{|c|}{0} & \multicolumn{2}{|c|}{7} & \multicolumn{2}{|c|}{14} & \\
\hline & Mean & $\mathrm{SE}$ & Mean & SE & Mean & SE & \\
\hline DMI & $0.176 \mathbf{a}$ & 0.015 & $0.140 \mathbf{b}$ & 0.013 & $0.179 a$ & 0.016 & $* *$ \\
\hline EI & $4.409 a$ & 0.428 & $3.136 \mathbf{b}$ & 0.302 & $4.177 \mathbf{a}$ & 0.384 & $* * *$ \\
\hline PI & $0.068 \mathbf{a}$ & 0.006 & $0.055 \mathbf{b}$ & 0.005 & 0.059ab & 0.006 & * \\
\hline
\end{tabular}

${ }^{(1)}$ DMI: dry matter intake, kg/d ; EI: energy intake, MJ/d; PI: protein intake, kg/d.

${ }^{(2)}$ Means with different superscripts are statistically different, $* * * \mathrm{P}<0.001 ; * * \mathrm{P}<0.01 ; * \mathrm{P}<0.05$.

Average grower concentrate intake increased with time in both treatment groups (Table 4). Although the grower intake of kids in the PROB group in the first week of the study was numerically higher than in the CONT group, this difference disappeared at the end of the $2^{\text {nd }}$ week of the study. Daily average grower intakes of kids in preweaning period (0-2 week) were 0.130 and $0.146 \mathrm{~kg} / \mathrm{head}$ for the CONT and PROB groups, respectively.

The increase in grower concentrate intake in the first week after weaning in comparison to the suckling period was by $131 \%$ for the CONT group and by $118 \%$ for 
the PROB group. In this week, daily average grower concentrate intakes for the CONT and PROB groups were $0.453 \mathrm{~kg} / \mathrm{d}$ and $0.412 \mathrm{~kg} / \mathrm{d}$, respectively. When daily average grower concentrate dry matter intake in post-weaning period (3-6 week) was evaluated on the group level, it appeared that the pattern of concentrate dry matter intake of the CONT group was highly variable, however that of the PROB group increased gradually (Figure 2b). Daily average grower intakes of the CONT and PROB groups for the post-weaning period were $0.397 \mathrm{~kg} / \mathrm{d}$ and $0.491 \mathrm{~kg} / \mathrm{d}$, respectively. Postweaning period was taken into account in the determination of feed efficiency as grower feed intake was quite low in the pre-weaning period. Feed efficiency for the post-weaning period was calculated as 9.03 for the CONT group and 6.09 for the PROB group.

Table 4

Average grower concentrate intakes of kids, kg DM/d (Durchschnittliche Aufzuchtfutteraufnahme der Lämmer, $\mathrm{kg} \mathrm{TM/Tag)}$

\begin{tabular}{ccccccc}
\hline \multirow{2}{*}{ Weeks } & \multicolumn{7}{c}{ Groups $^{(1)}$} \\
\cline { 2 - 7 } & A & CONT & C & A & PROB & C \\
\cline { 2 - 7 } & 0.065 & 0.007 & 0.013 & 0.103 & 0.011 & 0.020 \\
$1-2$ & 0.195 & 0.019 & 0.034 & 0.189 & 0.018 & 0.032 \\
$2-3$ & 0.453 & 0.038 & 0.071 & 0.412 & 0.034 & 0.063 \\
$3-4$ & 0.446 & 0.035 & 0.066 & 0.504 & 0.039 & 0.074 \\
$4-5$ & 0.256 & 0.020 & 0.038 & 0.500 & 0.036 & 0.069 \\
$5-6$ & 0.431 & 0.032 & 0.062 & 0.504 & 0.036 & 0.071 \\
Pre-weaning & 0.130 & 0.014 & 0.024 & 0.146 & 0.015 & 0.026 \\
Post-weaning & 0.397 & 0.032 & 0.060 & 0.491 & 0.036 & 0.069 \\
Overall & 0.308 & 0.028 & 0.052 & 0.376 & 0.031 & 0.058 \\
\hline
\end{tabular}

${ }^{(1)}$ CONT: control; PROB: probiotic; A: daily intake (kg); B: intake as the proportion of live weight

(LW, kg); intake as the proportion of metabolic weight $\left(\mathrm{LW}^{0.75}\right)$.

Daily water intakes were $0.147 \mathrm{l} /$ head for the CONT group and $0.260 \mathrm{l} / \mathrm{head}$ for the PROB group during the pre-weaning period and increased rapidly following weaning (1.355 l/head for the CONT group; 1.686 l/head for the PROB group). Overall daily water intakes followed a pattern which was similar to daily feed intake in both groups and were $0.952 \mathrm{l} /$ head and $1.211 \mathrm{l} /$ head for the CONT and PROB groups, respectively (Figure 3a).
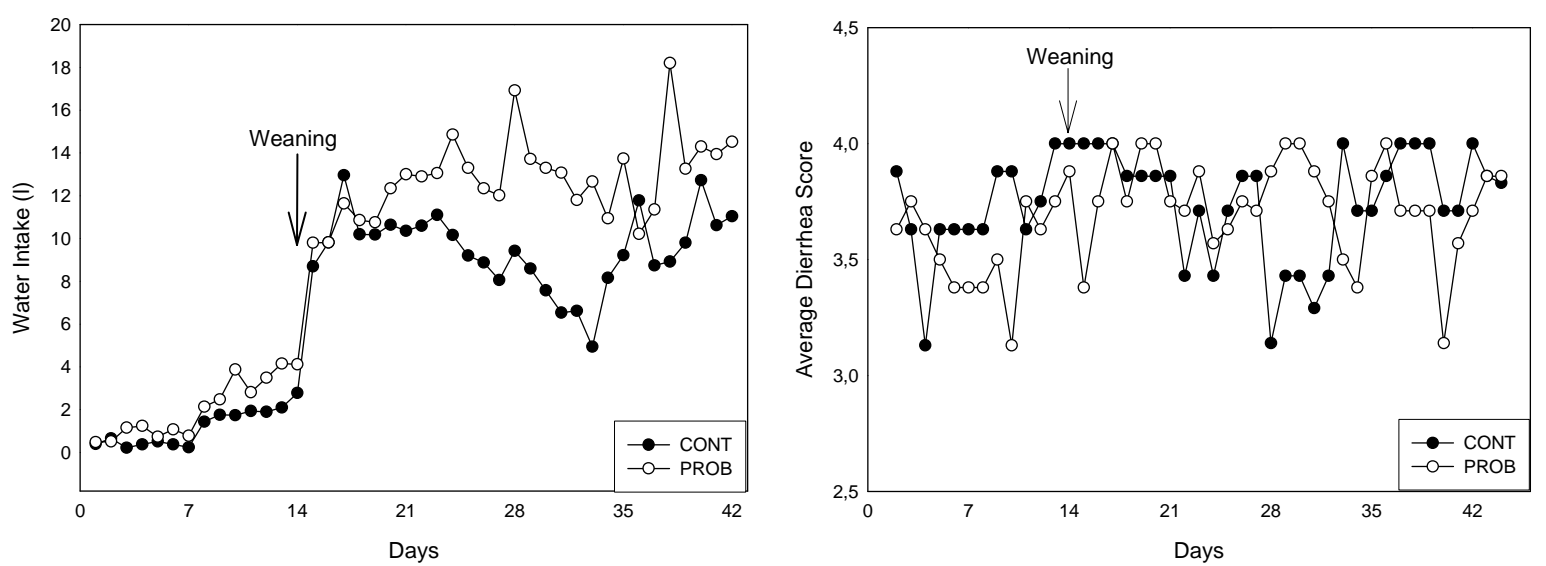

Fig. 3: Daily water intakes (a) and average diarrhea scores (b) of groups (Mittelwerte der Wasseraufnahme (a) und die Durchfallquote der Lämmer (b))

GEE parameter estimates indicated that probiotic supplementation did not affect diarrhea score $(\mathrm{P}>0.05)$. Although the difference between the groups was small, the 
PROB group had a slightly higher diarrhea score (Figure 3b). The distribution of frequencies of diarrhea scores (1, 2, 3 and 4) was 1.3, 3.4, 15.0 and $80.3 \%$ for the CONT group, and 3.3, 4.4, 11.2 and $81.1 \%$ for the PROB group. The distribution of diarrhea scores was not affected by day or day $\times$ treatment interaction $(\mathrm{P}>0.05)$. The effect of live weight on diarrhea score was significant $(\mathrm{P}<0.05)$ and positive $(\mathrm{b}=0.29)$. In other words, heavier kids had higher diarrhea scores and showed less diarrhea cases. Mean temperature and relative humidity of the barn were $20.0 \pm 0.34{ }^{\circ} \mathrm{C}$ and $37.0 \pm 1.05 \%$. Average breath number of kids was $50.95 \pm 2.09$ breath $/ \mathrm{min}$ and $51.00 \pm 2.04$ breath/min for the CONT and PROB groups. Probiotic supplementation had no significant effect on breath number $(\mathrm{P}>0.05)$, but the difference between observation days was found significant $(\mathrm{P}<0.001)$. No effect of day $\times$ treatment interaction on breath number was determined $(\mathrm{P}>0.05)$. Rectal temperature of kids was recorded as $39.18 \pm 0.064{ }^{\circ} \mathrm{C}$ and $39.19 \pm 0.069{ }^{\circ} \mathrm{C}$ for the CONT and PROB groups, respectively. No effect of treatment, day or day $\times$ treatment interaction $(\mathrm{P}>0.05)$ on rectal temperature in both groups was determined.

\section{$4 . \quad$ Discussion}

Supplementation of probiotics is expected to improve weight gain, feed efficiency and health parameters. Probiotics are used to modulate the composition of the gut microbial population; encouraging the proliferation and colonization of beneficial microbial species and in turn, suppressing the capacity of pathogenic microorganisms in the gut (HERICH et al., 1998). Disruption of colonization of the gut microbial population by various factors in neonatal life makes an individual susceptible to environmental factors. It is therefore suggested that probiotics should be supplemented as early as possible in neonatal life (CRUYWAGEN et al., 1996). In this regard, the present study which involved the supplementation of probiotics to kids aging at an average of 6 weeks is different from other studies where the probiotic supplementation was performed in younger animals. Probiotic supplementation was initiated shortly before weaning, which has a great impact on well-being and development of young animals, especially on kids. Weaning period is a critical time interval for kids in which growth rate slows down, even stops and sometimes weight loss can occur. The level of weaning shock largely depends upon weaning age, live weight and feeding conditions (MORAND-FEHR et al., 1982; PETERS and LAES-FETTBACK, 1995). Weaning period and weaning conditions can therefore be defined as the most crucial factors leading to the development of stress-causing conditions for kids.

The results of the present study indicated that the use of a probiotic cocktail including different microorganisms did not affect weight gain of kids $(\mathrm{P}>0.05)$. However it should be pointed out that weight change of kids after weaning followed a different pattern in which kids in the PROB group lost comparatively less weight than kids in the CONT group. Live weight data of kids should however be considered cautiously due to the number of kids in each group and the variation in weight of kids within each group. Live weight and weight gain values of kids from the present study are similar to the live weight and weight gain of kids of the same genotype (UGUR et al., 2004). The results of various studies aiming at looking at the effect of probiotic use on performance of neonatal calves are variable. The use of probiotics influenced live weight gain in this period in some studies (HERICH et al., 1998; ABU-TARBOUSH et al., 1996). CRUYWAGEN et al. (1996), who used L. acidophilus as probiotic, 
reported that probiotics could be effective in the first two weeks of the neonatal life of calves and can be used as a protecting feed additive against disease-causing factors.

The analyses of data obtained from the dams which were fed at the same level during the suckling period indicated that kids in both groups received similar amounts of milk nutrients (Table 2) and the amount of milk consumption was not changed by the probiotic supplementation ( $\mathrm{P}>0.05)$. The decrease in milk consumption in both groups on $\mathrm{d} 6$ of the study can be explained by the vaccination application. Variations in milkbased dry matter and nutrients intakes in both groups on the observation days are likely due to the variations in milk composition of the dams (Table 3).

Studies with calves demonstrated that supplementation of probiotics had no effect on liquid, starter or dry matter intakes (DONOVAN et al., 2002). The dry matter intakes of kids in both groups were quite similar in pre-weaning period (Figure 2b and Table 4). However the increase in the dry matter intakes of kids in the PROB group was rather consistent during four weeks after weaning. It is known that adaptation to dry feed in neonatal life is influenced mainly by liquid intake and other applications enhancing the development of rumen epithelia and capacity. Results of NAKANISHI et al. (1993) suggested that probiotics could stimulate rumen development.

Milk efficiency (kg milk/kg weight gain) during the suckling period was not affected by the probiotic supplementation $(\mathrm{P}>0.05)$. Feed efficiency for post-weaning period of kids in the PROB group was better than that of kids in the CONT group (6.09 vs. 9.03). However weight loss in the CONT group at the $4^{\text {th }}$ week should be taken into account when the difference in feed efficiency is considered (Figure 1b). The effect of probiotics on feed efficiency in calves is variable. HERICH et al. (1998) and SCHWAB et al. (1980) reported a trend toward improved starter intake and feed efficiency when calves were supplemented with probiotics. In contrast, feed efficiency is not altered by feeding probiotics to young calves (CRUYWAGEN et al., 1996; DONOVAN et al., 2002).

Development of ruminal and intestinal microbial population and quick adaptation to dry feed in neonatal ruminants are two major objectives to suppress the proliferation of enteropathogens which cause diarrhea cases. The use of probiotics is therefore expected to improve health status rather performance of animals via reducing the risk or level of diarrhea (KREHBIEL et al., 2003). Abrupt changes in feeding of animals or environmental conditions, which are regarded as stress-causing factors, often result in imbalances in the intestinal microbial population, which increases the risk of onset of diarrhea (TANNOCK, 1983). Some of the workers suggest that lack of difference in the effect of probiotics on diarrhea score can be explained by the absence of stresscausing factors in such trials (CRUYWAGEN et al., 1996; DONOVAN et al., 2002). KREHBIEL et al. (2003) found it surprising that calves had no health problems in studies where no benefit of probiotics use was observed. In the present study, supplementation of probiotics had no effect on diarrhea score $(\mathrm{P}>0.05)$. The diarrhea scores 3 or over of the CONT and PROB groups were determined as $95.3 \%$ and 92.3\%, respectively. This case indicated that no diarrhea problem occurred at a significant level. Breath numbers and rectal temperatures of kids recorded during the study are typical of this specie (MATTHEWS, 1999) and are within the normal physiological ranges. These parameters are also quite crucial in describing health status of animals. 
As far as our knowledge is concerned there is no single report on the efficacy of probiotics use under extensive husbandry conditions where the control of environmental conditions is quite difficult as opposed to intensive husbandry conditions under which probiotics sometimes improve animal performance. In the present study, the use of probiotics shortly before and after weaning did not have any significant effect on weight gain, nutrient intake, feed efficiency and diarrhea score in kids. However positive trend toward weight gain, feed intake and feed efficiency in the PROB group is encouraging for researchers to undertake further studies on probiotics use under extensive conditions. Further studies should focus on factors such as microbial composition of the supplementation, application dose and time and their interactions with environmental conditions.

\section{References}

ABU-TARBOUSH, H.M.; AL-SAIADY, M.Y.; KEIR EL-DIN, A.H.:

Evaluation of diet containing Lactobacilli on performance, fecal coliform, and Lactobacilli of young dairy calves. Animal Feed Science and Technology, 57 (1996), 39-49

ASSOCIATION OF OFFICIAL ANALYTICAL CHEMISTS.:

Official methods for analysis of the Association of Official Analytical Chemists, $15^{\text {th }}$ edition.

BEDÖ, S. Association of Official Analytical Chemists, Washington, DC, (1990)

Wirkung der Fütterung von Salinomycin und Flavomycin auf die Verdaulichkeit der Nahrstoffe der Futterration, der Zellwandbestandteile und auf den Nahrwert bei Schafen. Arch. Tierz., Dummerstorf 39 (1996) 3, 277-291

CRUYWAGEN, C.W.; JORDAAN, I.; VENTER, L.:

Effect of Lactobacillus acidophilus supplementation of milk replacer on pre-weaning performance of calves. Journal of Dairy Science, 79 (1996), 483-486

DONOVAN, D.C.; FRANKLIN, S.T.; CHASE, C.C.L.; HIPPEN, A.R.:

Growth and health of holstein calves fed milk replacers supplemented with antibiotics or enteroguard. Journal of Dairy Science, 85 (2002), 947-950

FULLER, R.:

A review: Probiotics in man and animals. Journal of Applied Bacteriology, 66 (1989), 365-378

GFE.:

Recommendations for the supply of energy and nutrients to goats. Ausschuss für Bedarfsnormen der Gesellschaft für Ernährungsphysiologie, DLG, Verlag, (2003)

GORSKI, P.; NIZNIKOWSKI, R.; STRZELEC, E.; POPIELARCZYK, D.; GAJEWSKA, A.; WEDRYCHOWICZ, H.:

Prevalence of protozoan and helminth internal parasite infections in goat and sheep flocks in Poland. Arch. Tierz., Dummerstorf, 47 (2004) Special Issue, 43-49

HERICH, R.; BOMBA, A.; NEMOCOVA, R.; GANCARCIKOVA, S.:

The influence of application of probiotic on the immune system of 2-3 month old calves. Arch. Tierz., Dummerstorf 41 (1998) 6, 565-572

JONSSON, E.:

Lactobacilli as probiotics to pigs and calves: A microbiological approach. Swedish University of Agricultural Sciences Department of Animal Nutrition and Management, Report 148, Uppsala, Sweden, (1985).

KREHBIEL, C.R.; RUST, S.R.; ZHANG, G.; GILLILAND, S.E.:

Bacterial direct-fed microbials in ruminant diets: performance response and mode of action. Journal of Animal Science, 81 (E. Suppl. 2), (2003), E120-E132

KUMAR, S., VIHAN, V.S., DEOGHARE, P.R.:

Economic implication of diseases in goats in India with reference to implementation of a health plan calendar. Small Ruminant Research, 47 (2003), 159-164

LAES-FETTBACK, C.; PETERS, K.J.:

A comparative study of performance of Egyptian goat breeds. II: Growth performance and productivity. Arch. Tierz., Dummerstorf 38 (1995) 5, 563-575

LIANG, K.Y.; ZEGER, S.L.:

Longitudinal data analysis using generalized linear models. Biometrika, 73 (1986), 13-22

LIPSITZ, S.H.; KIM, K.; ZHAO, L.: 
Analysis of repeated categorical data using generalized estimating equations. Statistics in Medicine, 13 (1994), 1149-1163

MATTHEWS, J.:

Diseases of the goat, $2^{\text {nd }}$ edition. Blackwell Science, Inc., Malden MA, U.S.A, 364, (1999)

MCCULLAGH, P.; NELDER, J.A.:

Generalized linear models. Chapman\&Hall, New York, (1989)

MORAND-FEHR, P.; HERVIEU, J.; BAS, P.; SAUVANT, D.:

Feeding of young goats. Proceedings of the Third International Conference on Goat Production and Disease. Tucson, Arizona U.S.A., 90-104, (1982)

NAKANISHI, Y.; ARAVE, C.W.; STEWART, P.H.:

Effects of feeding Lactobacillus acidophilus yogurt on performance and behavior of dairy calves. Journal of Dairy Science, 76 (Suppl. 1), (1993), 244

PETERS, K.J.; LAES-FETTBACK, C.:

A comparative study of performance of Egyptian goat breeds. I. Reproductive and dairy performance. Arch. Tierz., Dummerstorf 38 (1995) 1, 93-102

SAS,:

SAS Institute Inc., SAS OnlineDoc ${ }^{\circledR}$, Version 8.0, Cary, NC: SAS Institute Inc., (1999)

SNOEYENBOS, G.H.:

The gut microflora: The first line of defense of any animal. In: Biotechnology in the Feed Industry, Proceedings of Alltech's Fifth Annual Symposium, ed. by T.P. Lyons. Alltech Tecnical Publications, Nicholasville, Kentucky, 261-270, (1989)

SCHWAB, C.G., MOORE, J.J., HOTY, P.M., PRENTICE, C.G.:

Performance and fecal flora of calves fed a nonviable Lactobacillus bulgaricus fermentation product. Journal of Dairy Science, 63 (1980), 1412

TANNOCK, G.W.:

Effects of dietary and environmental stress on the gastrointestinal microbiota. In: Human Intestinal Microflora in Health and Disease, ed. by D. Hentges. Academic Press, New York, 517-539, (1983)

TOUKOUROU, Y.; PETERS, K.J.:

Auswirkungen restriktiver Ernährung auf die Wachstumsleistung von Ziegenlämmern. Arch. Tierz., Dummerstorf 42 (1999) 3, 281-293

UGUR, F.; SAVAS, T.; DOSAY, M.; KARABAYIR, A.; ATASOGLU, C.:

Growth and behavioral traits of Turkish Saanen kids weaned at 45 and 60 days. Small Ruminant Research, 52 (2004), 179-184

WINER, B.J.; BROWN, D.R.; MICHELS, K.M.:

Statistical principles in experimental design, $3^{\text {rd }}$ edition, McGraw-Hill Inc., USA, 1057 p, (1991)

Received: 2004-11-04

Accepted: 2005-10-28

Author's addresses

KEVSER AYIŞIĞI

Canakkale Onsekiz Mart University, Faculty of Agriculture Department of Animal Science, 17020 Canakkale / Turkey

Assist. Prof. Dr. CENGİZ ATAŞOĞLU (Corresponding author)

Canakkale Onsekiz Mart University, Faculty of Agriculture Department of Animal Science, 17020 Canakkale / Turkey

E-mail: catasoglu@comu.edu.tr

Assoc. Prof. Dr. İSMAİL YAMAN YURTMAN

Canakkale Onsekiz Mart University, Faculty of Agriculture Department of Animal Science, 17020 Canakkale / Turkey

E-mail: soneryam@comu.edu.tr

Assist. Prof. Dr. MEHMET MENDEŞ

Canakkale Onsekiz Mart University, Faculty of Agriculture Department of Animal Science, 17020 Canakkale / Turkey

E-mail:mmendes@comu.edu.tr

Assist. Prof. Dr. AKIN PALA

Canakkale Onsekiz Mart University, Faculty of Agriculture Department of Animal Science, 17020 Canakkale / Turkey

E-mail: akin@comu.edu.tr 